\title{
WASTE WOOD OF URBAN ORIGIN FOR ENERGY USE ${ }^{1}$
}

\author{
Carlos Rogério Andrade ${ }^{2 *}$, Ananias Francisco Dias Junior ${ }^{2}$, José Otávio Brito ${ }^{3}$, Thiago de Paula Protasio ${ }^{4}$, \\ Paulo Fernando Trugilho ${ }^{5}$ and Isabel Cristina Nogueira Alves de Melo ${ }^{6}$
}

\footnotetext{
${ }^{1}$ Received on 21.05.2015 accepted for publication on 28.11.2016

${ }^{2}$ Escola Superior de Agricultura "Luiz de Queiroz" - Universidade de São Paulo, Programa de Pós-Graduação em Recursos Florestais, Piracicaba, São Paulo, Brasil. E-mail: <cra.florestal@yahoo.com.br> and < ananiasjuniorr@gmail.com>.

${ }^{3}$ Escola Superior de Agricultura "Luiz de Queiroz" - Universidade de São Paulo, Departamento de Ciências Florestais, Piracicaba, São Paulo, Brasil. E-mail: <jobrito@usp.br>.

${ }^{4}$ Universidade Federal de Lavras, Doutorado em Ciência e Tecnologia da Madeira, Lavras, Minas Gerais, Brasil. E-mail: $<$ depaulaprotasio@gmail.com>.

${ }^{5}$ Universidade Federal de Lavras, Departamento de Ciências Florestais, Lavras, Minas Gerais, Brasil. E-mail: <trugilho@dcf.ufla.br>. ${ }^{6}$ Universidade Federal de Lavras, Doutorado em Ciência e Tecnologia da Madeira, Lavras, Minas Gerais, Brasil. E-mail: <bebelcrist@yahoo.com.br>.

*Corresponding author.
}

\begin{abstract}
The increasing demand for energy propels new areas of research in the search for sources that are economically viable and sustainable from an environmental point of view. In this sense, the objective of this study was to characterize a batch from urban wood waste aimed at energy use. We evaluate six different types of waste: solid wood, plywood, chipboard, MDF, OSB, and veneer. The residues were collected in a recycling plant in Piracicaba - SP and were taken to the laboratory to carry out the physical, chemical and thermogravimetric analyses. The experiment was conducted in a completely randomized design with three replicates per treatment (waste). Data analysis was performed by analysis of variance (ANOVA) and the Tukey test applied for multiple comparisons of means. Overall, there were no major differences between the results of solid wood residues and waste panels. Waste analyzed showed potential for energy use. It is recommended further studies to investigate the influence of different panels resins and coatings in its thermal degradation process.
\end{abstract}

Keywords: Energy woody biomass; Panels; Wood chips for fuel

\section{RESÍDUOS DE MADEIRA DE ORIGEM URBANA VISANDO USO ENERGÉTICO}

\begin{abstract}
RESUMO - A crescente demanda por energia impulsiona novas frentes de pesquisas na busca por fontes que sejam economicamente viáveis e sustentáveis do ponto de vista ambiental. Neste sentido, o objetivo deste trabalho foi caracterizar um lote de residuos de madeira de origem urbana visando uso energético. Foram avaliados seis diferentes tipos de resíduos: madeira maciça, compensado, aglomerado, MDF, OSB e chapa. Os resíduos foram coletados em uma estação de reciclagem no município de Piracicaba-SP e foram levados ao laboratório para realização das análises fisicas, químicas e termogravimétricas. O experimento foi conduzido sob um delineamento inteiramente casualizado com três repetições por tratamento (resíduos). Para análise dos dados foi realizada a análise de variância (ANOVA) e aplicado o teste de Tukey para comparações múltiplas das médias. De maneira geral, não foram observadas grandes diferenças entre os resultados dos resíduos de madeira maciça e os resíduos de painéis de madeira. Os resíduos analisados apresentam potencial para uso energético. Recomenda-se novos estudos para verificar a influência das resinas e dos diferentes revestimentos de painéis no seu processo de degradação térmica.
\end{abstract}

Palavras-chave: Energia da biomassa lenhosa; Painéis; Cavacos para combustivel. 


\section{INTRODUCTION}

The use of biomass residues in Brazil has proven to be a promising alternative for generating income and mitigating impacts for both the private and the public sectors. This is especially true after the approval of Law 12,305 / 2014, which instituted the National Solid Waste Policy in the country.

Regarding the reuse of wood waste, Macfarlane (2009) draws attention to those of urban origin, since they can reliably offer a significant amount of wood with potential for use as fuel sources and heat/energy generation. This also contributes to the reduction of fossil fuels, as well as reducing pressure on destroying forests.

In Brazil, the generation of waste originates, above all, in the industrial activities of logging and also in urban areas, which in turn derive from the civil construction, afforestation, and defective packaging sectors (Brasil, 2009a). Lyon and Bond, (2014) still include wood leftovers from homes renovations, discarded old furniture, crates, and defective pallets.

Data from the Ministry of the Environment (Brasil, $2009 \mathrm{~b}$ ) estimate that the construction sector and urban areas alone account for 2.79 million tons of wood waste in the country, for which the most common destinations are: landfills for civil works; landfill for sanitary waste; landfill for inert material; Recycling stations; and irregular waste deposits.

To be used for energy purposes, the wood should not have moisture content above $20 \%$, as higher values reduce the heat capacity of the combustion, the temperature of the firing chamber, and the temperature of the exhaust gas (Farinhaque, 1981). According to Brito (1986), the presence of water represents a negative calorific value, due to the fact that part of the released energy is spent in the vaporization and that very significant variations in the moisture content can hinder the combustion process. Such effects would lead to constant adjustment of system settings. Brand and Muñiz (2012) verified that the chemical composition, calorific value, and humidity of the forest biomass suffer variations in relation to the time of storage. This situation, to a certain extent, resembles the conditions observed for final disposal piles of urban wood waste, thus justifying their characterization.

As for the energy potential of wood panels from old furniture that are discarded in the trash, Farage et al. (2013) found that the technical and economic feasibility for its reuse is directly related to its moisture, heat, and ash.

In addition to the mentioned characteristics, the thermogravimetric evaluation of the material (TGA) is of great importance. Through TGA, it is possible to quantify the combustion and decomposition characteristics of the fuels reliably and simply, which can provide a prediction for the combustion efficiency, boiler projects being an example (Vamvuka and Sfakiotakis, 2011; Yuzbasi and Selçuk, 2011; Moon et al., 2013).

Therefore, there are many properties that can interfere with the energetic use of the wood, and in the case of wood that is discarded in the garbage, limited information is available in the literature. Thus, the objective was to evaluate the energy potential of wood residues present in municipal solid waste in the city of Piracicaba - SP.

\section{MATERIALS AND METHODS}

\subsection{Material e Amostragem}

Six types of wood waste were evaluated: a) solid wood, b) MDF panels, c) plywood panels, d) chipboard, e) oriented structure board (OSB), and f) veneer.

The samples were provided by a recycling company based in the city of Piracicaba - SP. Sampling of residues was conducted according to standard NBR 10007 (ABNT, 2004). 240 samples of solid wood residues and 240 samples of panel residues were collected. The samples were stored in plastic bags and sent to the laboratory for further identification and analysis.

\subsection{Physical Properties}

\section{Moisture Content}

The moisture content was evaluated in the residues in their original forms, as collected in the field. The procedure used was NBR 14929 (ABNT, 2003).

\section{Bulk Density}

Bulk density was performed according to procedure NBR 6922 (ABNT, 1981). Samples of industrial chips 
processed in the waste recycling plant were used. Part of the chips was sent for other analysis.

\subsection{Chemical Composition}

The lignin content was obtained according to standard TAPPI 222 05-74, (1974). The total extractives content was obtained according to standard TAPPI T-264 (1993). Holocellulose content was determined by the difference.

\subsection{Immediate Constituent Analysis}

The immediate constituent analysis was carried out to determine the volatile materials, ashes, and fixed carbon according to procedure NBR 8112 (ABNT, 1986).

\subsection{Higher Calorific Value}

The higher calorific value was determined using an Ika C200 bomb calorimeter according to procedure NBR 8633 (ABNT, 1984).

\subsection{Thermogravimetric analysis}

The equipment used was a SHIMADZU DTG-60H. The test had an initial temperature of $30^{\circ} \mathrm{C}$ and a final temperature of $600^{\circ} \mathrm{C}$, with a heating rate of $10^{\circ} \mathrm{C} \cdot \mathrm{min}^{-1}$. A nitrogen flow of $50 \mathrm{~mL} . \mathrm{min}^{-1}$ was used. The first derivative of the TG curve, which establishes mass loss as a function of temperature, was used to identify the rate of mass loss per second and the peaks characteristic of thermal degradation of biomass.

\subsection{Statistical Analysis}

The data were submitted to analysis of variance (ANOVA) using a completely randomized design with three replicates per treatment (residues) and, when necessary, the Tukey test was applied for multiple comparisons of the means. The analysis was performed using Minitab16.1® software and Microsoft Excel's Action supplement, all at 95\% probability.

\section{RESULTS}

The results for the different types of residues sampled, percentages in dry mass, respective moisture contents, and bulk density are listed in Table 1 .

In analyzing Table 1 , it can be noticed that the largest participation was $56 \%$ for solid wood residues when considering the universal sample. Within the group of panels, the largest numbers of samples were for plywood residues, representing $23 \%$ of the total dry mass collected, followed by residues of MDF, chipboard, veneer, and OSB, with 10\%, 23\%, 4\% 4\%, and $3 \%$, respectively.

In relation to the moisture content, the highest value found was from MDF residues, with $15 \%$ moisture content, and the lowest value was veneer with $10.24 \%$. It is important to note that the residue moisture contents is close to the average equilibrium humidity of the collection municipality, which is $12.9 \%$ (Jankowsky and Galina, 2013). This is viewed as satisfactory for drying of the material in consideration of energy.

For the bulk density results, the highest observed value was for solid wood with $0.183 \mathrm{~g} . \mathrm{cm}^{-3}$, being statistically equal to the plywood, chipboard, and OSB. The MDF and veneer had the lowest density 0.104 g. $\mathrm{cm}^{-3}$ and 0.139 g. $\mathrm{cm}^{-3}$, respectively. This result may have been observed because MDF and veneer are produced from fibers that would better fit the spaces in the measuring vessel.

Table 2 shows the total extractive, holocellulose, and lignin contents of the analyzed solid residues.

It can be observed in Table 2 that the average

Tabela 1 - Teor de umidade médio dos resíduos sólidos amostrados.

Table 1 -Average moisture content of the sampled waste.

\begin{tabular}{lcccc}
\hline Residues & $\mathrm{N}$ & $\mathrm{MS}(\mathrm{g})$ & TU (\%) & $\mathrm{DG}_{\left(\mathrm{g} . \mathrm{cm}^{-3}\right)}$ \\
\hline Solid wood & 240 & $68.84[56]$ & $12.26(34.07)$ & $0.183(1.01) \mathrm{a}$ \\
Plywood & 92 & $28.54[23]$ & $12.73(34.32)$ & $0.177(517) \mathrm{a}$ \\
Chipwood & $23.32[4]$ & $13.93(31.16)$ & $0.168(2.94) \mathrm{a}$ \\
MDF & 76 & $12.48[10]$ & $15.00(28.86)$ & $0.104(2.03) \mathrm{c}$ \\
OSB & $2.98[3]$ & $11.01(40.01)$ & $0.168(4.96) \mathrm{a}$ \\
Veneer & 29 & $4.52[4]$ & $10.24(42.85)$ & $0.139(1.06) \mathrm{b}$ \\
\hline
\end{tabular}

N: Number of Samples. MS: Dry Weight. TU: Base Moisture Content. DG: Bulk Density. Values between brackets [ ] represent the percentage of dry mass of each type of waste in relation to the total collected. Values between parenthesis ( ) are the variation coefficients of the analyzed wastes. 
Tabela 2 - Teores de extrativos totais, de holocelulose e de lignina.

Table 2 - The content of total extractives, holocelulose and lignin.

\begin{tabular}{lccr}
\hline Resídues & ET (\%) & THO (\%) & L (\%) \\
\hline Solid Wood & $16.67(1.14) \mathrm{a}$ & $51.76(0.21) \mathrm{c}$ & $31.57(0.94) \mathrm{bc}$ \\
Plywood & $12.14(1.79) \mathrm{cd}$ & $53.21(2.34) \mathrm{bc}$ & $34.65(3.56) \mathrm{a}$ \\
Chipwood & $12.51(1.18) \mathrm{c}$ & $56.64(0.46) \mathrm{b}$ & $30.84(0.86) \mathrm{bc}$ \\
MDF & $14.26(0.79) \mathrm{b}$ & $57.08(2.01) \mathrm{b}$ & $28.65(4.16) \mathrm{c}$ \\
OSB & $11.26(0.91) \mathrm{d}$ & $55.63(3.59) \mathrm{bc}$ & $33.10(5.86) \mathrm{ab}$ \\
Veneer & $11.78(7.69) \mathrm{cd}$ & $64.15(3.86) \mathrm{a}$ & $24.06(6.87) \mathrm{d}$ \\
\hline
\end{tabular}

ET: Total extractives content; THO: holocelulose content; L: lignina content; Values between parenthesis ( ) are the variation coefficients of the analyzed wastes.

total extractive content for solid wood was higher than the other residuals analyzed. One possible explanation may be the possibility of this segment being formed by an unknown number of species, native or not. Another possibly is that it presents higher extractive contents in its composition as compared to Pinus sp. and Eucalyptus sp, which are traditionally used in the manufacturing of reconstituted panels.

The highest holocellulose content was $64.15 \%$ for veneer, and the lowest was for solid wood with $51.76 \%$. Regarding the lignin contents, the highest values were for OSB and plywood with $33.10 \%$ and $34.65 \%$, respectively.

Figure 1 shows the average values of ash, volatile materials, fixed carbon, and higher calorific value of the analyzed solid residues.

The mean values found for the fixed carbon contents are statistically the same for the analyzed residues.

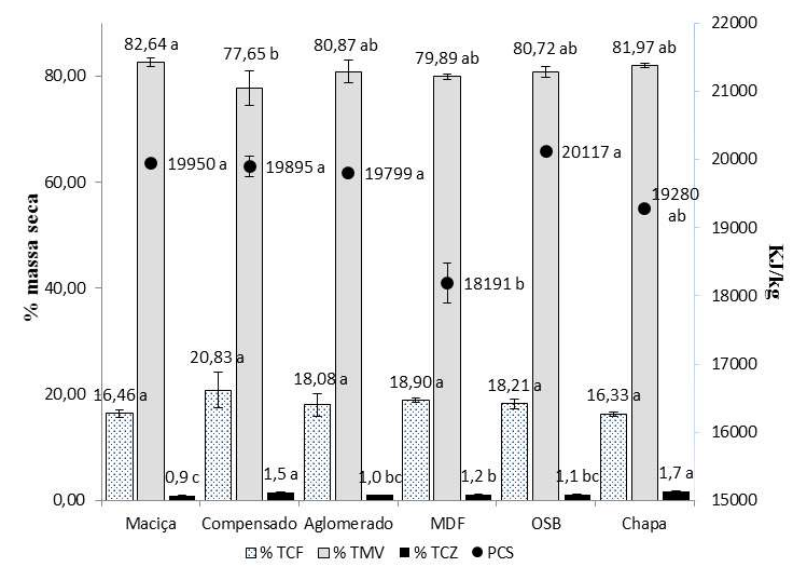

Figura 1 - Análise química imediata dos resíduos e poder calorífico superior.

Figure 1 - Immediate constituent analyses of waste and higher calorific value.
On the other hand, the volatile materials are repeated only when considering the panel residues.

From the absolute point of view, the maximum value observed for fixed carbon was $20.83 \%$ for plywood residues, and the maximum for volatile materials was $82.64 \%$ for solid wood residues. For ash values, the results ranged from $0.9 \%$ to $1.7 \%$ for solid wood and veneer, respectively. As for the higher calorific value, the highest observed value was for the residues of

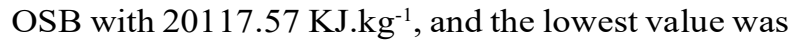
for MDF of $18191.65 \mathrm{KJ}_{\mathrm{kg}} \mathrm{kg}^{-1}$.

The mass loss as a function of temperature (TG curve) of the residues is presented in figure 2 .

Three distinct regions can be observed: the 1 st region (with temperatures from 30 to $230^{\circ} \mathrm{C}$ ) is where volatization of water and extractives occur; the 2 nd region (with temperatures from 230 to $370{ }^{\circ} \mathrm{C}$ ), the release of volatile materials occurs; and in the $3 \mathrm{rd}$

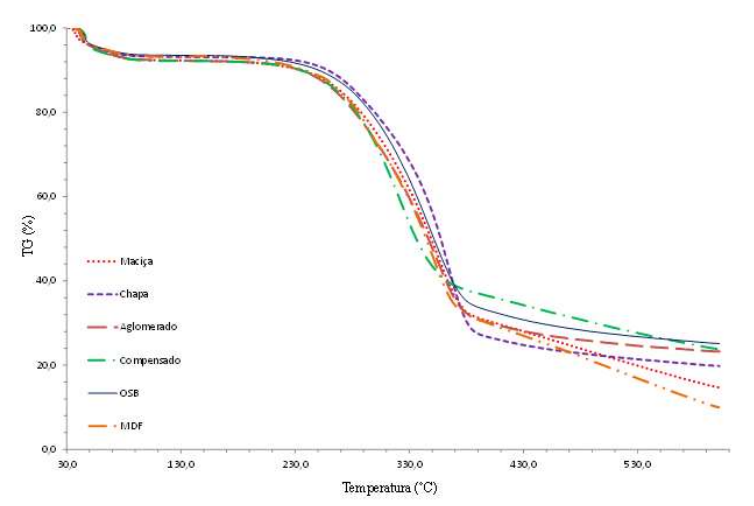

Figura 2 - Perda de massa em função da temperatura para os diferentes resíduos lenhosos.

Figure 2-Weight loss versus temperature for different waste timber. 


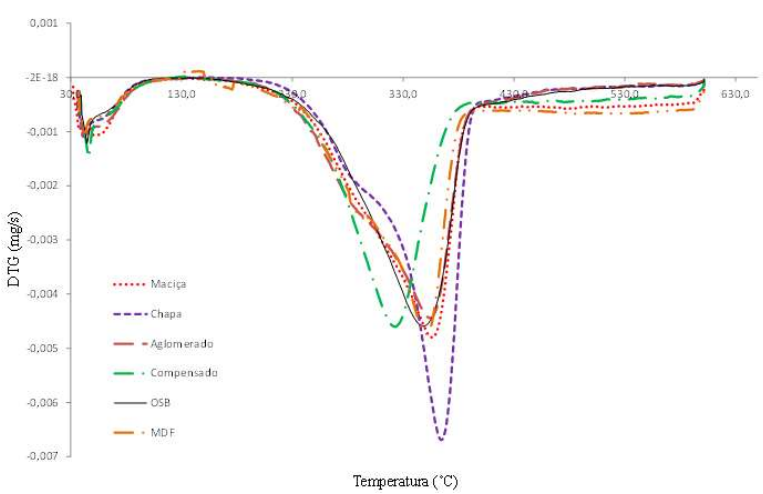

Figura 3 - Curvas de DTG para os resíduos lenhosos analisados. Figure 3-DTG curves for wood residues analyzed.

region (with temperatures above $370^{\circ} \mathrm{C}$ ), pyrolysis reactions occur.

The DTG curves graph for the analyzed residues is shown in Figure 3.

Analyzing the DTG curves (Figure 2), a certain similarity between the curves for solid wood, chipboard, OSB, and MDF can be observed. It is also observed that there is a formation of a higher intensity inverted peak for veneer residues in the $340^{\circ} \mathrm{C}$ range, inferring that this is the moment of maximum degradation of the hemicelluloses of this material. This, in turn, can be explained by its high content of holocellulose $(64.15 \%)$, which was verified during the chemical analyzes.

\section{DISCUSSION}

\section{Dry Weight}

Solid wood residues had a higher share of dry mass when compared to veneer, probably due to the fact that it presented higher bulk density.

\section{Moist ure}

The values found for moisture content are in accordance with those reported in the literature. According to the work of Farage et al. (2013), which evaluated wood pulp residues from furniture in Ubá-MG, moisture levels were found to be $22.7 \%$ for plywood, $10.3 \%$ for MDF, ranging from $9.8 \%$ to $10.3 \%$ for chipboard, and between $16.5 \%$ and $17.8 \%$ for solid wood. The equilibrium humidity for the municipality of Ubá is $14.37 \%$ (Lima and Mendes, 1995), which is slightly above that reported for the city of Piracicaba and, therefore, should also justify the higher moisture content of the plywood found in the literature. In addition to the influence of environmental conditions, one must also consider the conditions of sampling, time of year, size of the pile, and time of exposure of the waste to the elements. For the remaining residues, the values were very close to those of this work.

\section{Bulk Density}

Farage et al. (2013) found the bulk density of MDF residue values to be $303 \mathrm{~kg} \cdot \mathrm{m}^{-3}$, and $200 \mathrm{~kg} \cdot \mathrm{m}^{-3}$ for solid wood, the latter being close to what was found in this work.

\section{Chemical Analysis}

The values found in this work for chemical analysis are in agreement with those reported by Morais; et al. (2005), who studied wood of Pinus oocarpa and found extractive contents of $11.8 \%$ and lignin content of $25.18 \%$. In studies by Barbosa et al. (2014), the authors evaluated residues of Pinus elliottii and found holocellulose contents of $61.79 \%$ and lignin content of $26.40 \%$. Silva et al. (2014) studied four species of tropical wood and found total extractive contents varying between $3.55 \%$ and $7.68 \%$, holocellulose varying from $58.68 \%$ to $70.55 \%$, and lignin varying between $25.13 \%$ and $33.64 \%$.

On the other hand, Ferreira (2013) studied MDF wood waste from the furniture sector and found values of $13.9 \%$ for extractives in water, $50.7 \%$ for cellulose, $22.3 \%$ for hemicellulose, and $13.1 \%$ for lignin. In this case, the values were $15.92 \%$ higher for holocellulose (cellulose + hemicellulose) and 15.55\% lower for lignin compared to those found in the current study. One possible explanation may be that they are residues from different origins whose variations in relation to their chemical characteristics are not yet well known.

The results for ash contents are in accordance with those reported by Farage et al. (2013), which found ash content for MDF, solid wood, plywood, and chipboard to be $0.74 \%, 0.48 \%, 0.79 \%$, and $0.95 \%$, respectively.

\section{Calorific Potential and Immediate Constituent Analysis}

The values of higher calorific value, volatile materials, fixed carbon, and ash are very close to those reported in literature for similar woody biomass. Farage et al. (2013) reported higher calorific values of 19811.94 KJ.kg-1 for MDF, $19803.56 \mathrm{KJ}^{-\mathrm{kg}^{-1}}$ for solid wood, 18501.47 
KJ.kg-1 for plywood, and 18953.64 KJ.kg-1 for chipboard.

Poletto; et al. (2014) found MDF values of 78.3\% for volatile materials, $21.17 \%$ for fixed carbon, $0.53 \%$ for ash, and $19005 \mathrm{KJ}^{\mathrm{kg}} \mathrm{kg}^{-1}$ for calorific value.

Yorulmaz and Atimtay, (2009) analyzing MDF panels found $86.68 \%$ to be volatile materials, $11.06 \%$ for fixed

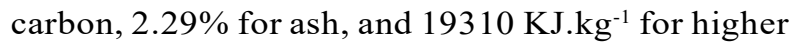
calorific value.

Souza et al.(2012), studying waste from Pinus taeda, found values of volatile materials varying from $82.57 \%$ to $86.24 \%$, fixed carbon varying from $13.44 \%$ to $17.01 \%$, ash ranging from $0.20 \%$ to $0.42 \%$, and higher calorific value varying between $18987 \mathrm{KJ} . \mathrm{kg}^{-1}$ and $20624 \mathrm{KJ} . \mathrm{kg}^{-1}$.

In a study by Silva et al. (2014) on four types of tropical wood residues, the authors found values of volatile materials varying from $80.94 \%$ to $82.76 \%$, fixed carbon varying from $16.99 \%$ to $18.94 \%$, ash ranging from $0.119 \%$ to $0.562 \%$, and higher calorific value ranging from $19292 \mathrm{KJ} . \mathrm{kg}^{-1}$ to $20632 \mathrm{KJ} . \mathrm{kg}^{-1}$.

The similarity between the results found in the literature and those obtained in this work suggests promising potential in the use of these residues for energy purposes.

\section{T G A - D T G}

The analysis of the temperature ranges of this work is similar to that found by Kercher and Nagle (2001) for MDF, and close to the flammability range (270$280^{\circ} \mathrm{C}$ ) found by Vamvuka et al, (2015) in mixtures of urban wood waste.

Above $370{ }^{\circ} \mathrm{C}$, the plywood and OSB residues presented greater thermal stability when compared to the others. This can be explained by the higher lignin content of these residues (Figure 1). This result is in accordance with those found by Sharma et al. (2004); Yang et al. (2006); Protásio et al. (2013), who verified that lignin provides greater thermal stability when compared to the other molecular groups. This is due to the carbon-carbon bonds between the monomeric phenyl propane units, and consequently, the stability of their aromatic matrix, in addition to the high molecular weight.

At the end of the treatment, the highest degradation or loss of mass was verified for the MDF panels. This group was followed by solid wood, which proved to

Revista Árvore. 2017;41(2):e410208 have the lowest lignin content in the chemical analysis, confirming the previous reasoning.

The fact that most of the panel residues presented higher thermal stability when compared to solid wood residues suggests that the resins, used as binders and different types of coatings and finishes common in the manufacturing of panels, may present greater stability than the wood when subjected to combustion tests. However, this impression needs to be confirmed by further research.

Different results were observed by Protásio et al. (2013), who showed degradation peaks at $288.9^{\circ}$ $\mathrm{C}$, and in works by Poletto et al. (2012) with a peak of $300^{\circ} \mathrm{C}$ for eucalyptus sawdust.

In a study by Kim et al. (2006), the authors defined the range of $180^{\circ} \mathrm{C}$ and $350^{\circ} \mathrm{C}$ for hemicelluloses degradation. Shafizadeh (1985), defined the degradation range for cellulose being between $305^{\circ} \mathrm{C}$ and $375^{\circ} \mathrm{C}$ and lignin between $250{ }^{\circ} \mathrm{C}$ and $500{ }^{\circ} \mathrm{C}$. In this same context, Popescu et al. (2011) found that wood components behave differently if they are isolated or closely linked. The authors studied the degradation of different species of wood and verified that the degradation of hemicellulose begins around $170{ }^{\circ} \mathrm{C}$ and extends up to $380^{\circ} \mathrm{C}$; Lignin degradation also starts at $170{ }^{\circ} \mathrm{C}$ and extends to temperatures above $600^{\circ} \mathrm{C}$; the degradation of the cellulose occurs between 280 and $400{ }^{\circ} \mathrm{C}$.

Thus, the results found for the DTG curves are within the standards surveyed in the literature, supporting the idea use of these wastes for energy. Although no clear influence of panel resins on TG/DTG curves has been observed in the present work, a more detailed analysis of the degradation of these binder compounds is recommended in future work.

\section{CONCLUSION}

The wood residues present in urban solid waste that were analyzed in this work presented characteristics similar to the traditional woody biomass used for energy purposes and, therefore, have a promising potential for this purpose.

In general, residues of solid wood and residues of wood panels showed similar values for technological properties.

For thermal study of wood panels, special attention should be given to the possible influence of the resins 
and the different types of coatings common for panels when studying the process of thermal degradation.

\section{ACKNOWLEDGEMENTS}

The authors thank the Laboratory of Cellulose and Energy Chemistry (LQCE) of the Department of Forestry Sciences at the "Luiz de Queiroz" School of Agriculture - ESALQ, University of São Paulo - USP, Brazil as well as the Biomass Energy Laboratory of the Federal University of Lavras (UFLA), MG, Brazil. We would also like to thank Michael James Stablein of the University of Illinois Urbana-Champaign for his translation services and review of this work.

\section{REFERENCES}

Associação Brasileira de Normas Técnicas ABNT. NBR 6922: 1981: Carvão vegetal - ensaios físicos determinação da massa especifica (densidade a granel). Rio de Janeiro: 1981. 25p.

Associação Brasileira de Normas Técnicas ABNT. NBR 8112: 1986: Análise química imediata do carvão vegetal. Rio de Janeiro: 1986. 5p.

Associação Brasileira de Normas Técnicas ABNT. NBR 8633: 1984: Carvão vegetal Determinação do poder calorífico. Rio de Janeiro: 1984. 25p.

Associação Brasileira de Normas Técnicas ABNT. NBR 10007: 2004: Amostragem de resíduos sólidos. Rio de Janeiro: 2004. 25p.

Associação Brasileira de Normas Técnicas ABNT.NBR 14929: 2003: Determinação do teor de umidade de cavacos - Método por secagem em estufa.Rio de Janeiro: 2003. 25p.

Barbosa LC, Pedrazzi C, Ferreira ÉS, Schneid GN, Wille VKD. Avaliação dos resíduos de uma serraria para a produção de celulose $\mathrm{Kraft}$. Ciência Florestal. 2014;24(2):491-500.

Brand MA, Muñiz GIB. Influência da época de colheita e da estocagem na composição química da biomassa florestal. Floresta e Ambiente. 2012;19(1):66-78.

Brito JO. Madeira para a floresta: a verdadeira realidade do uso de recursos florestais.
Silvicultura. 1986;11(41):188-93.

Farage RMP, Rezende AAP, Silva CM, Nunes WG, Carneiro ACO, Vieira DB et al. Avaliação do potencial de aproveitamento energético dos resíduos de madeira e derivados gerados em fábricas do polo moveleiro de ubá - MG. Ciência Florestal. 2013;23(1):203-12.

Farinhaque R. Influência da umidade no poder calorífico da madeira de bracatinga (Mimosa scrabella, Benth) e aspectos gerais de combustão. Curitiba: FUPEF; 1981. 14p. (Série técnica, 6)

Ferreira SD. Estudo da viabilidade da conversão térmica de resíduos de fibra de média densidade (mdf) [dissertação]. Caxias do Sul: Universidade de Caxias do Sul; 2013.

Jankowsky IP, Galina ICM. Secagem de madeiras. Piracicaba; ESAIQ/ITTO; 2013.

Kercher AK, Nagle DC. TGA modeling of the thermal decomposition of CCA treated lumber waste. Wood Science and Technology. 2001;35(4):325-41.

Kim HS, Kim S, Kim HJ, Yang HS. Thermal properties of bio-flour-filled polyolefin composites with different compatibilizing agent type and content. Thermochimica Acta. 2006;451(1-2):181-8.

Lima JT, Mendes LM. Estimativa da umidade de equílibrio para madeiras em trinta e duas cidades do Estado de Minas Gerais. Revista Árvore. 1995;19(2):272-6.

Lyon S, Bond B. What is urban wood waste/? Forest Products Journal. 2014;64(5-6):166-70.

Macfarlane DW. Potential availability of urban wood biomass in Michigan: Implications for energy production, carbon sequestration and sustainable forest management in the U.S.A. Biomass and Bioenergy. 2009;33(4):628-34.

Brasil. Ministério do Meio Ambiente. Aproveitamento de resíduos e subprodutos florestais, alternativas tecnológicas e propostas de políticas ao uso de resíduos florestais para fins energéticos. Curitiba: 2009a.

Brasil. Ministério do Meio Ambiente.

Revista Árvore. 2017;41(2):e410208 
Levantamento sobre a geração de resíduos provenientes da atividade madeireira e proposição de diretrizes para políticas, normas e condutas técnicas para promover o seu uso adequado. Curitiba: 2009b.

Moon C, Sung Y, Ahn S, Kim T, Choi G, Kim D. Effect of blending ratio on combustion performance in blends of biomass and coals of different ranks. Experimental Thermal and Fluid Science. 2013;47:232-40.

Morais SAL, Nascimento EA, Melo DC. Análise da madeira de Pinus oocarpa parte I: estudo dos constituintes macromoleculares e extrativos voláteis. Revista Árvore. 2005;29(3):461-70.

Poletto M, Dettenborn J, Pistor V, Zeni M, Zattera AJ. Materials produced from plant biomass . Part I/ : Evaluation of thermal stability and pyrolysis of wood 3. Results and discussion. Materials Research. 2010;13(3):3759.

Poletto M, Ornaghi Júnior HL, Zattera AJ. Native cellulose: structure, characterization and thermal properties. Materials. 2014;7(9):6105-19.

Poletto M, Zattera AJ, Forte MMC, Santana RMC. Thermal decomposition of wood: Influence of wood components and cellulose crystallite size. Bioresource Technology. 2012;109:48-153.

Popescu MC, Popescu CM, Lisa G, Sakata Y. Evaluation of morphological and chemical aspects of different wood species by spectroscopy and thermal methods. Journal of Molecular Structure. 2011;988(1-3):65-72.

Protásio TP, Melo ICNA, Guimarães Junior M, Mendes RF, Trugilho PF. Thermal decomposition of torrefied and carbonized briquettes of residues from coffee grain processing. Ciência e Agrotecnologia. 2013;37(3):221-8.

Shafizadeh F. Pyrolytic reactions and products of biomass. In: Overend RP, Milne TA, Mudge LK,

Revista Árvore. 2017;41(2):e410208 editors. Fundamentals of biomass thermochemical conversion. London: Elsevier; 1985. p.183-217.

Sharma RK, Wooten JB, Baliga VL, Lin X, Chan WG, Hajaligol MR. Characterization of chars from pyrolysis of lignin. Fuel. 2004;83(11/12):1469-82.

Shebani AN, van Reenen AJ, Meincken M. The effect of wood extractives on the thermal stability of different wood-LLDPE composites.

Thermochimica Acta. 2008;481(1-2):52-6.

Silva DA, Almeida VC, Viana LC, Klock U, Muñiz GIB. Avaliação das propriedades energéticas de resíduos de madeiras tropicais com uso da espectroscopia NIR. Floresta e Ambiente. 2014;21(4):561-8.

Souza MM, Silva DA, Rochadelli R, Santos RC. Estimativa de poder calorífico e caracterização para uso energético de resíduos da colheita e do processamento de Pinus taeda. Floresta. 2012;42(2):325.

Technical Association of the Pulp and Paper Industry - TAPPI. TAPPI 222 05-74. Tappi: Acid insoluble lignin in wood and pulp. Standart Methods. Atlanta: 1974.

Technical Association of the Pulp and Paper Industry - TAPPI. TAPPI T264. Tappi: Preparation of wood for chemical analysis. Standart Methods. Atlanta: 1993.

Vamvuka D, Sfakiotakis S. Combustion behaviour of biomass fuels and their blends with lignite. Thermochimica Acta. 2011;526(1-2):192-9.

Vamvuka D, Sfakiotakis S, Saxioni S. Evaluation of urban wastes as promising co-fuels for energy production - A TG/MS study. Fuel. 2015;147:17083.

Yang H, Yan R, Chen H, Zheng C, Lee DH, Liang DT. In-Depth investigation of biomass pyrolysis based on three major components:

Hemicellulose, cellulose and lignin. Energy \& Fuels. 2006;20(1)388-93

Yorulmaz SY, Atimtay A. Investigation of combustion kinetics of five waste wood samples with thermogravimetric analysis. Environmental Earth Sciences. 2009;90(7-8):511-20.

Yuzbasi NS, Selçuk N. Air and oxy-fuel combustion characteristics of biomass/lignite blends in TGA-FTIR. Fuel Processing Technology. 2011;92(5):1101-8. 